\title{
Resilience of the US securities industry to the global financial crisis
}

\author{
Dariusz Wójcik and Theodor Cojoianu ${ }^{\mathrm{b}}$
}

${ }^{a}$ Corresponding author: School of Geography and the Environment, Oxford University, South Parks Road, OX 1 3QY UK. Email: dariusz.wojcik@ouce.ox.ac.uk

${ }^{\mathrm{b}}$ School of Geography and the Environment, Oxford University, South Parks Road, OX $130 Y$

UK. Email: theodor.cojoianu@ouce.ox.ac.uk

\begin{abstract}
The global financial crisis was underpinned by the securitization of subprime mortgages led by US investment banks, and its outbreak was marked by the bankruptcy of Lehman Brothers on 15 September 2008. This paper investigates the resilience of the US securities industry to this shock and its evolution between 2008 and 2016, with focus on employment, location, remuneration, sell-side versus buy-side dynamics, and gender. Results show that the US securities industry has suffered significant losses in terms of employment and its recovery has been slow. Under the pressures of depressed demand, new regulation and cost cutting, the industry has gone through significant adaptation in terms of corporate reorganisation, value chain optimisation, market reorientation and innovation, but has not yet adapted in terms of remuneration. The buy-side of the industry has performed much better than the sell-side in terms of resistance and recovery. The patterns of resistance and recovery have been highly uneven across states and cities. While the top of the hierarchy of securities industry centres has not changed significantly in terms of ranking, large centres, with New York in the lead, have suffered larger job losses than smaller centres, reflecting a significant spatial dispersion of employment in the industry. Male employment has proven more resilient than female employment highlighting continued gender inequality and lack of diversity.
\end{abstract}

Keywords: financial crisis, financial centres, investment banking, asset management, restructuring, gender

\section{Funding sources}

The project has received funding from the European Research Council (ERC) under the European Union's Horizon 2020 research and innovation programme (grant agreement number 681337). The article reflects only the authors' views and the ERC is not responsible for any use that may be made of the information it contains.

\section{Introduction}

Investment banks have been at the epicenter of the subprime crisis in the USA, and its transmission to Europe and the rest of the world, which led to what is referred to as the global financial crisis (GFC) or the great recession (Sorkin, 2010; Tett, 2009). They are the key players in the securities industry involved in the production and circulation of financial securities and derivatives. Albeit with significant interruptions, the securities industry had boomed between the late 1970s and 2008 in the US, and this boom has spread to the rest of 
the world, accompanied by the growth of capital markets, cross-border capital flows, securitization of different forms of credit (from mortgages to car and student loans) and the invention of new types of securities and financial derivatives. Over thirty years ago Susan Strange described investment banks as croupiers in casino capitalism (1986). Recently, the economic, political, social and cultural power of investment banks in the world, and particularly the US, has been captured in the term 'investment bank capitalism' (Wójcik, 2012). This term drew attention to investment banks as keystone species of contemporary capitalism, waging extraordinary influence not only in the world of financial markets, corporations and governments, but also in shaping the very way we perceive and measure the world economy. When we consider concepts such as emerging markets, frontier markets, BRICs, or value at risk, all of those owe their popularity, if not conception, to investment banks.

Investment banks, hedge funds and other securities firms feature as main characters (mostly culprits) in many books on the roots of the GFC and the ongoing reform of the international financial system (Lewis, 2010; Sorkin, 20010; Tett, 2009), but to the best of our knowledge there are no systematic accounts of how the industry as a whole has changed since the crisis. Surely, if we recognise the position of securities industry at the fulcrum of a system that failed, we need to investigate whether it has changed sufficiently to give us hope that the system will operate better in the future. With the tenth anniversary of Lehman Brothers' collapse fast approaching as we write, the time is ripe for such an analysis. Geography is particularly well-suited to the task, as it allows us to consider a wide range of economic, political, social, cultural and technological factors, which all potentially shape the post-crisis transformation of the securities industry or lack thereof.

In this context, the goal of the paper is to investigate the resilience of the US securities industry to the GFC and its evolution between 2008 and 2016. The US is not only the source of the GFC but also the cradle of the modern securities industry and by far its biggest market (Morrison and Wilhelm, 2007). The GFC has fueled interest in resilience in social and economic sciences, including geography. In the latter, focus on regional resilience has recently been complemented with studies on sectoral resilience. Geographical research applying a resilience perspective to finance, however, has been extremely rare, with no studies focusing on the securities industry, despite the fact that this was the industry at the very epicenter of the GFC. An additional reason making such an application important is the position of the securities industry as the elite of the financial and business services complex (Wójcik, 2018). Financial and business services as a whole have become central to urban and regional economies not only in terms of their size but also their overall resilience. They are considered to be innovative and adaptable, with high capacity to assimilate, exploit and transform new ideas and diffuse them across their regions (Storper and Scott, 2009). They attract highly-skilled human capital that contributes to regional entrepreneurialism and offer high salaries that imply large local multiplier effects. Finally, they affect the availability of capital in cities and regions (Wójcik, 2011). As such, asking whether and how the securities industry, particularly in the US, has resisted and adapted to the GFC has relevance for understanding the future of capitalism as well as regional and urban development trajectories.

The paper will proceed as follows. In the next section, we will develop a conceptual framework for the paper, by reviewing geographical literature on resilience and applying it 
to the securities industry. The following four sections will explore the resilience of the US securities industry to the GFC, starting with broad patterns of resistance and recovery (section 3), delving into sub-sectoral patterns (section 4), analysis across regions and cities (section 5), and finishing with resilience in relation to gender. The concluding section will elaborate on what the results tell us about the nature of change in the US securities industry, its future trajectory, and further research needed on this topic.

\section{The conceptual framework: sectoral resilience and the securities industry}

Resilience can be defined as "the ability of a system to undergo anticipatory or reactionary reorganization of form and/or function so as to minimize the impact of a destabilizing shock" (Martin, 2012, 5). The geographical literature distinguishes between three basic types of resilience. Engineering resilience involves the ability of a region to return to a preshock growth trend (or business as usual). Ecological resilience means that a shock throws a region past a threshold, beyond which a return to the pre-crisis growth path is impossible. Instead the region embarks on a new development path, which may involve slower or faster growth. Finally, adaptive resilience, which derives from the theory of complex adaptive systems, stresses the ability of a system to reconfigure and adapt its structure so as to maintain an acceptable level of activity and growth (Boschma, 2015; Boschma and Frenken, 2006).

Studies on resilience also distinguish between two major dimensions of the process. The first is resistance understood as vulnerability or sensitivity to disturbances and disruptions. The second is recovery from a shock, including the renewal of a growth path and the possibility of structural re-orientation, also referred to as re-alignment or adaptation. In this paper we are interested in both resistance and recovery and engage with the concept of adaptive resilience. We consider the GFC as a major existential crisis of the US securities industry, which opens a possibility, if not necessity, for structural re-orientation and adaptation.

The study of resilience begs a four-part question: resilience of what, to what by what means, and with what outcome? Of what concerns delimiting the system in question, how resilience is measured, and criteria used to determine if the system has changed its structure or function as a result of a shock. The system in question in our paper is the US securities industry. The primary function of the industry is the production and circulation of securities, which help companies and governments raise capital and match both, as issuers of securities, with institutional and individual investors. This intermediary function leads to an important distinction between the sell-side and buy-side of the industry. Sell-side, with investment banks in the lead, works primarily with issuers of securities; buy-side, with asset managers in the lead, serves mainly investors. Sell-side is more wholesale-oriented, highvalue, low-volume business, focused on big deals for big customers. Buy-side is more retailoriented, low-value, high-volume business, focused on process, and a more bureaucratic, low-profile activity. Throughout the paper we recognize the nature of the US securities industry as an open system. US securities firms have international presence and foreign firms have presence in the US. Capital, services, labour and other markets in which securities firms operate are highly integrated internationally, if not globally (Wójcik, 2011). 
While employment is the critical variable for studying regional resilience, for an industry it would be ideal to use both employment and output. To measure resilience we use employment data, complemented, where possible, with data on revenues and profits. Unfortunately output data is limited and available only for the whole country or for individual firms, often operating internationally. The US Census offers quarterly data on employment in the securities industry, its location, payroll, and gender structure. This data allows us to investigate not only the overall size but also the structure of the industry along three dimensions: sell- and buy-side as its key subsectors, spatial distribution of employment including securities industry centres, and gender. Payroll data offers us a chance to go beyond raw employment figures and delve deeper into structural responses to the crisis. Focusing on employment, its location and payroll, we focus on resilience for employees of securities firms and places of employment rather than on resilience for the shareholders/owners of the industry. We take the 'whose resilience' question seriously by extending our analysis to gender. While many existing studies consider diversity as an input, a factor that in most cases affects resilience positively (Martin and Sunley, 2015), we also consider it as an output, affected by the process of resilience.

The shock in question is the GFC, which erupted in full in the US in September 2008 with recession lasting until late 2009 . There is little doubt that the GFC has had a major impact on the US securities industry, mainly through depressed demand for their services and new regulation. Since 2008 returns on securities and financial markets in general have been at historically low levels. One major reason is a slowdown in the global economy, combined with high uncertainty. Another reason is the unprecedented level of government and central bank intervention in financial markets, with headline interest rates close to zero, and in some countries, even below zero. Economists refer to this situation as financial repression, whereby governments keep interest rates below inflation rate, thus transferring wealth from savers/lenders to borrowers. Alongside savers, the financial sector becomes repressed in the process as well.

The GFC has unleashed a wave of new regulation. This was led by the 850-page long DoddFrank Wall Street Reform and Consumer Protection Act in the US, signed into law in 2010. The body of new regulations based on Dodd-Frank Act has now exceeded 10,000 pages and has been supplemented with numerous international regulations led by the Financial Stability Board, housed by the Bank for International Settlements in Basel. Regulatory changes focus on higher capital requirements, restrictions on proprietary trading (in contrast to trading on clients' accounts) called Volcker rule, stricter disclosure requirements, more responsibility for internal risk management, and restrictions on securitization of loans. These have been accompanied by regular stress tests of banks conducted by the Federal Reserve Bank, to simulate how they would perform under crisis conditions, and numerous lawsuits conducted by federal agencies, against investment banks in particular, related to mis-selling of securities, market manipulation, and other misdeeds. US investment banks have paid over $\$ 100$ bn in fines since 2008 (The Economist, 2016). To be sure, the securities industry, as key players in the financial sector lobby, has worked hard to influence the reforms, both in the US and internationally, and in many respects the reforms to date should be considered inadequate (Bayoumi, 2017; Helleiner, 2014). 
The question of resilience by what means concerns mechanisms and processes by which a system, sector in this case, reacts to the shock. Here our starting point is the classification of process fields of adjustment (or mechanisms of sectoral resilience) proposed by FromholdEisebith (2015). Market reorientation involves sales shifting to less crisis-affected areas; value chain optimization is about "reorganization of supplier and outsourcing relations for reducing cost and improving the division of labour" (Fromhold-Eisebith, 2015, 1683); strategic corporate reorganization involves mergers and acquisitions, sale of corporate branches and strategic alliances. The remaining three processes are: innovation, including knowledge and skills upgrading; relocation of production, resulting in its concentration and/or opening new, more efficient plants; and finally 'ecosystem dynamics of firm demographics, which "captures the overall demographic dynamics involving end producers, suppliers of components and services in the industry, which emerge from the sum of all transformative changes instigated by the global shock" (Fromhold-Eisebith, 2015, 1689; Reggiani et al., 2002). Fromhold-Eisebith (2015) considers this to be a rough sequence of the processes of sectoral resilience, which motivates us to test not only how important they were for the resilience of the US securities industry to the GFC, but also reflect on their sequence. One mechanism that does not feature explicitly in Fromhold-Eisebith's scheme is salary/wage reduction, though perhaps it could feature as part of value chain optimization. This factor is listed by Martin and Sunley (2015) as a major firm-level adjustment strategy, and is highly relevant to the securities industry, in/famous for high salaries and bonuses, which according to some contributed to the GFC itself (Johnson and Kwak, 2010), and presumably create a lot of room for cost reduction.

The question of the outcomes of resilience is concerned with the speed, extent and nature of recovery. To address this question, we analyse the evolution of the US securities industry all the way until early 2016, for which the latest US Census data are available. After all, the GFC is considered the biggest financial crisis in the US since the great crash of 1929 (Reinhart and Rogoff, 2009). The severity of the shock and regulation introduced in its train justifies the application of a long window of time for studying recovery. When analyzing the nature of recovery, we will focus, as elsewhere, on the sub-sectoral, spatial, and gender structure of employment and payroll.

Quantitative analysis forms the backbone of the paper, but it is enhanced with qualitative data based on a review of trade magazines and websites, with the Financial News, the American Banker, and the Wall Street Oasis online forum in the lead, as well as dozens of interviews with investment bankers and other finance professionals conducted since 2008 around the world, including US securities firms. Quantitative analysis allows us to assess the broad features of resistance, recovery and their structures, whereas qualitative sources help us reflect on the underlying forces and mechanisms. While interviews inform our understanding of this complex industry, we do not use quotes and let the narrative be driven by broad industry-wide patterns discerned from quantitative data and other publicly available information.

To the best of our knowledge, this paper is the first study of the resilience of the securities industry to the GFC, and the first geographical study of resilience in the financial sector in general. Research on resilience in finance, emerging in economics, is influenced by complexity economics, and focuses on the financial system as a whole and its vulnerability 
to crises (related to the issue of systemic risk), and on individual financial firms. Complexity economics has also had an impact on new regulation, for example through the concepts of resilience-enhancing redundancy, justifying higher capital requirements, and modularity, justifying calls for separation of investment from retail banking (Goldin and Mariathasan, 2014). While these are important, our primary focus here is on the securities industry as a subsector of the financial industry and its geography. Analysing employment, remuneration, location and gender allows us to consider seriously the social, political, and cultural in addition to the economic dimensions of resilience. As Martin and Sunley $(2015,9)$ stated "the ultimate goal should be to construct a political economy of regional resilience in the full meaning of the term". We hope our paper can contribute to this objective as well to a tradition of research in economic geography on corporate and industrial change and financial geography (Massey, 1984; Schoenberger, 1997; Martin and Pollard, 2017).

\section{Broad patterns of resistance and recovery}

Figure 1 shows the evolution of employment since the start of 2008 until the first quarter of 2016. Securities industry consists of two 3-digit NAICS categories: securities, commodity contracts, and other financial investments and related activities (523); and funds, trusts, and other financial vehicles (525). The whole financial sector is defined as FIRE (finance, insurance and real estate), consisting of: monetary authorities and central bank (521), securities industry (defined above), insurance (524), and real estate (531).

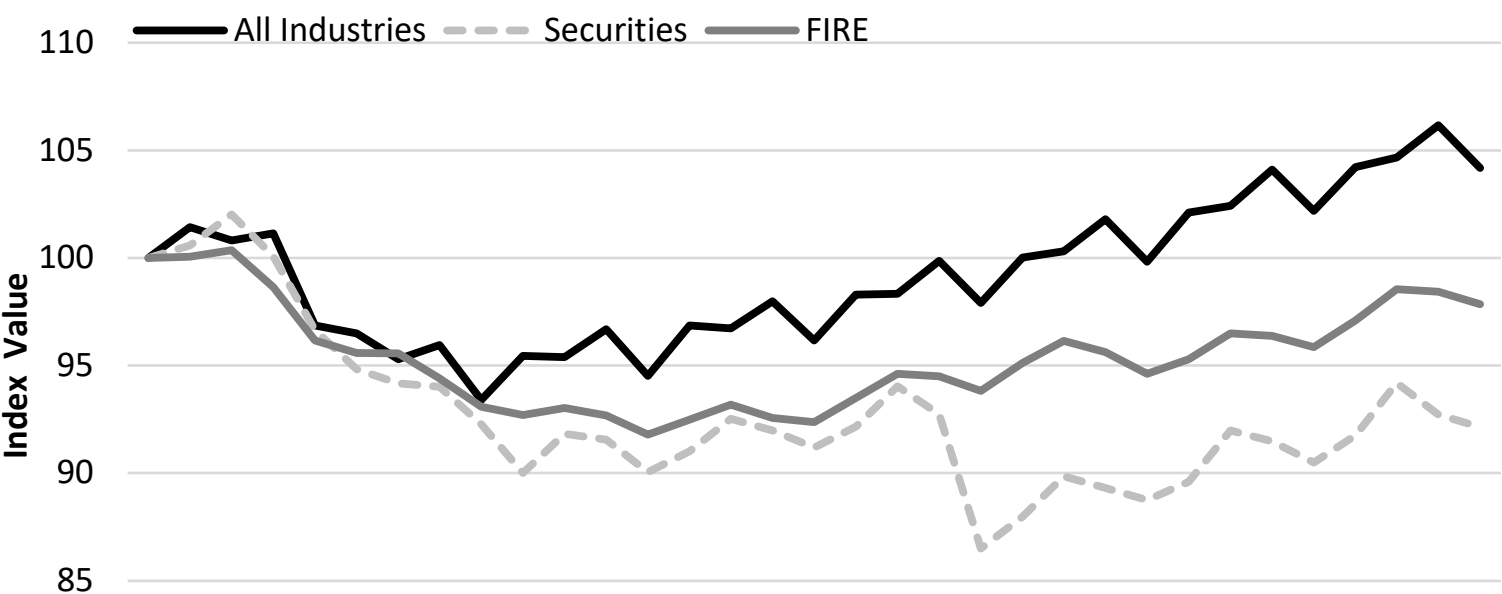

80

\begin{tabular}{llllllll|lllllllllllllllllllllllllll}
1 & 2 & 3 & 4 & 1 & 2 & 3 & 4 & 1 & 2 & 3 & 4 & 1 & 2 & 3 & 4 & 1 & 2 & 3 & 4 & 1 & 2 & 3 & 4 & 1 & 2 & 3 & 4 & 1 & 2 & 3 & 4 & 1
\end{tabular} \begin{tabular}{|l|l|l|l|l|l|l|l|}
2008 & 2009 & 2010 & 2011 & 2012 & 2013 & 2014 & 2015 \\
\hline
\end{tabular}

Year / Quarter

Fig. 1. Indices of employment in the US securities industry, financial sector (FIRE) and the whole economy.

Source: Authors based on data from the US Census and County Business Patterns (also for figures $3,5,6,7,8,9)$.

Note: The figure shows employment at the start of each quarter.

Employment in the securities industry started to fall during Q3 2008. By the end of that quarter, with Lehman Brothers, one of the largest investment banks, filing for bankruptcy, it 
was clear that the industry was facing a full-blown crisis. The decline continued until Q2 2010, shortly after the end of the US economic recession. Employment stabilized in 2010 and then increased until mid-2012, but suffered another major decline in the second half of 2012. It has recovered steadily since the start of 2013, but at the start of 2016, at 930,000 it was significantly lower than eight years earlier when it was 1,009,000.

To quantify resistance, table 1 shows a sensitivity index, calculated as the ratio of the percentage change in the securities industry employment between Q4 2008 and Q2 2010 to the percentage change in total US employment in this period. A recovery index, in turn, is calculated as the ratio of the percentage change in the securities industry employment between Q2 2010 and Q1 2016 to the percentage change in total US employment in this period. Sensitivity and recovery indices are also calculated for FIRE and key subsectors of the securities industry, using the same formulae. These ratios and figure 1 demonstrate that the securities industry employment was much more sensitive to the crisis than employment in the rest of the financial sector, not to mention the rest of the US economy. It is also clear that recovery in the securities industry employment has been much slower and much more fragile than in the rest of the financial sector and the US economy. This fragility is underscored by a major fall in employment in the second half of 2012. While financial market indices, such as S\&P500, the broad US equity market index, were stagnant in that period of time, highlighting the uncertainty of the US and global economic recovery, there is no obvious shock behind this fall in employment. In our view it should rather be interpreted as a delayed effect of the 2008-9 shock, with new regulations slowly coming into effect, and many securities firms realizing they need to make more radical changes to reduce costs than they thought were necessary in late 2008 and in 2009.

Table 1. Sensitivity and recovery of selected categories of US employment.

Source: Authors based on data from US Census Bureau and County Business Patterns.

\begin{tabular}{lrrrrrrr}
\hline & & Employment & & $\begin{array}{l}\text { Employment } \\
\text { Change }\end{array}$ & $\begin{array}{l}\text { Sensitivity } \\
\text { Index }\end{array}$ & $\begin{array}{l}\text { Q2 2010- } \\
\text { Q1 2016 }\end{array}$ & \multicolumn{1}{c}{$\begin{array}{l}\text { Q2 2010- } \\
\text { Q1 2016 }\end{array}$} \\
\cline { 2 - 8 } & 2008 Q4 & 2010 Q2 & 2016 Q1 & $\begin{array}{l}\text { Q4 2008- } \\
\text { Q2 2010 }\end{array}$ & $\begin{array}{l}\text { Q4 2008 - } \\
\text { Q2 2010 }\end{array}$ & $\begin{array}{l}\text { Employment } \\
\text { Change }\end{array}$ & $\begin{array}{l}\text { Recovery } \\
\text { Index }\end{array}$ \\
\hline All Industries & $131,915,381$ & $124,476,464$ & $135,869,368$ & $-5.64 \%$ & 1 & $8.45 \%$ & 1 \\
FIRE & $7,431,446$ & $6,984,370$ & $7,384,797$ & $-6.02 \%$ & 1.07 & $5.73 \%$ & 0.68 \\
Securities & $1,009,808$ & 908,231 & 929,700 & $-10.06 \%$ & 1.78 & $2.36 \%$ & 0.28 \\
Buy-side & 492,539 & 447,019 & 477,037 & $-9.24 \%$ & 1.64 & $6.72 \%$ & 0.79 \\
Sell-side & 508,942 & 453,962 & 448,133 & $-10.80 \%$ & 1.92 & $-1.28 \%$ & -0.15 \\
\hline
\end{tabular}

While data on the revenues and profits of the US securities industry, defined as the sum of the NAICS categories we use to study employment, is not available, as a proxy we can use data on all NYSE-reporting broker-dealers doing business in the USA. As we can see in figure 2 , after a fall in 2010-11, their revenues have been rising slowly. After record profits in 2009, attributed mainly to low interest costs, their pre-tax profits have fluctuated around $10 \%$ of revenues. While these figures look less dramatic than changes in employment, they do show that the post-crisis recovery of the industry has been slow and fragile. 


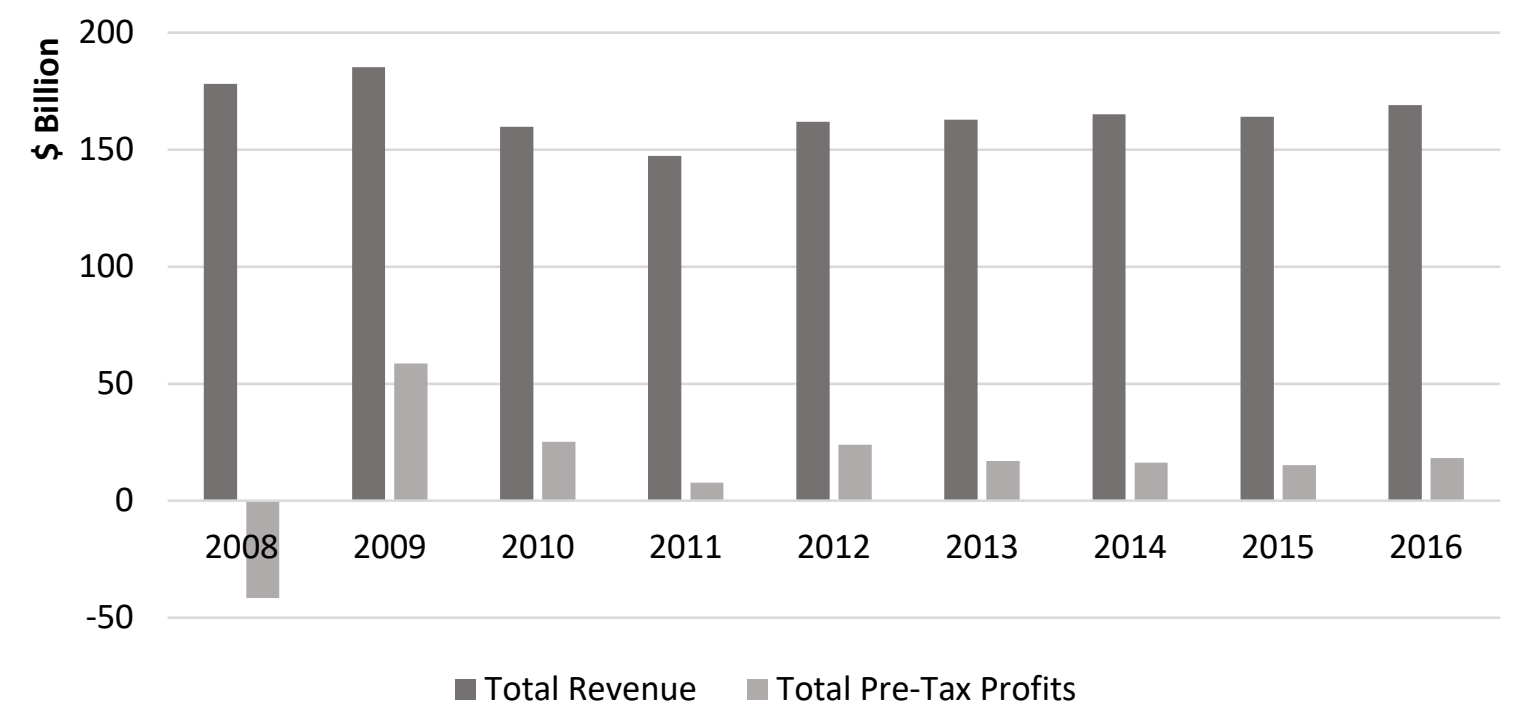

Fig. 2. Total revenue and pre-tax profits (\$bn) of NYSE-reporting broker-dealers. Source: Authors based on data from SIFMA (2017).

What factors are most likely to have affected the resilience of the US securities industry in terms of employment? In contrast to the sequence suggested by Fromhold-Eisebith (2015) we have to start with strategic restructuring. JP Morgan took over ailing Bear Sterns already in March 2008. A flurry of major mergers and acquisitions followed in late 2008. Bank of America purchased Merrill Lynch and Wachovia was purchased by Wells Fargo (Sorkin 2010). This process of corporate consolidation, often arranged by the US government and its agencies, was accompanied by significant layoffs, but ultimately prevented even bigger reduction in employment that would have taken place if more securities firms had gone bankrupt. While normally we would expect firms to use other means to respond to a crisis before resorting to strategic restructuring, the 2008 crisis was so severe that it required extraordinary responses.

As the GFC started in the USA and ignited the Eurozone crisis, the only major regional market less affected by the crisis was in Asia. US securities firms with strong presence in Asia could take advantage of that to compensate for their losses in the US and Europe. In Goldman Sachs and Morgan Stanley, two of the leading investment banks, for example, the share of Asia-Pacific in total fee income increase from $7 \%$ and $8 \%$ to $17 \%$ and $21 \%$ respectively (Wójcik et al., 2018b). There were limits to market reorientation and the relocation of production in the securities industry, however, as Asia-Pacific still constitutes a smaller market for securities industry services than America or Europe (Wójcik et. al. 2018).

There is evidence that securities firms engaged in various forms of value chain optimization or broadly speaking cost reduction, often combined with innovation and upgrading. In November 2008 Morgan Stanley announced plans to cut 10\% of its staff in the institutional securities division (The New York Times, 2008). In 2015, the same company decided to cut jobs in short-term credit and regional broker-dealerships. As returns and revenues in US capital markets declined, foreign banks found it increasingly difficult to compete with their US counterparts. In 2016, for example, Australia's Macquarie laid off $15 \%$ of its US investment banking employees (Reuters, 2016a). Employment decline in the US was also 
driven by offshoring. Goldman Sachs, for example, moved some of their US employees to Asian centres, including Singapore, where demand for capital market services has not suffered as much as it did in the USA (Huffington Post, 2011). Back- and mid-office jobs were increasingly being moved from the USA to lower-cost locations, with Asia and Eastern Europe in the lead (Massini and Miozzo, 2012; Grote and Täube, 2006). Already by the end of 2011, US banks were estimated to have outsourced IT and back office projects worth $\$ 5 b n$ to India (The Economic Times, 2011). In 2015, approximately $12 \%$ of the global workforce of the six largest US banks (Bank of America, Citigroup, JPMorgan, Morgan Stanley, Wells Fargo and Goldman Sachs) was in Asian support centres (Financial Times, 2017a). Job losses in the securities industry would have been much bigger if it was not for new regulation creating new jobs in compliance and risk management departments (McGrath and McNulty, 2014). New regulatory technology, however, allowed some of these jobs to be offshored as well (Financial Times, 2015).

An important mechanism of firm-level resilience involves reduction in remuneration. In the decades preceding the crisis, securities firms, and investment banks in particular, have become in/famous for some of the highest salaries and bonuses in the whole US economy (Philippon and Reshef, 2012). High remuneration has become the symbol of greed endemic in the industry and the target of social movements such as Occupy Wall Street.

Defying expectations of moderation, payroll per person in the securities industry increased in nominal terms, from $\$ 185 \mathrm{k}$ in 2008 to $\$ 205 \mathrm{k}$ in 2015 (figure 3). This increase of $11 \%$ was below the $2008-15$ inflation rate of $12.5 \%$, thus representing a slight, almost negligible decline in real terms. In the same period, average annual payroll per person in the financial industry increased by $18 \%$ and across all industries by $15.5 \%$. As such, remuneration in the securities industry remained out of touch with the rest of the economy, with average pay still 3.86 times higher than that in the whole economy, compared to 4.03 times higher in 2008. Data on bonuses in figure 4, available for New York-based securities firms confirms this finding.

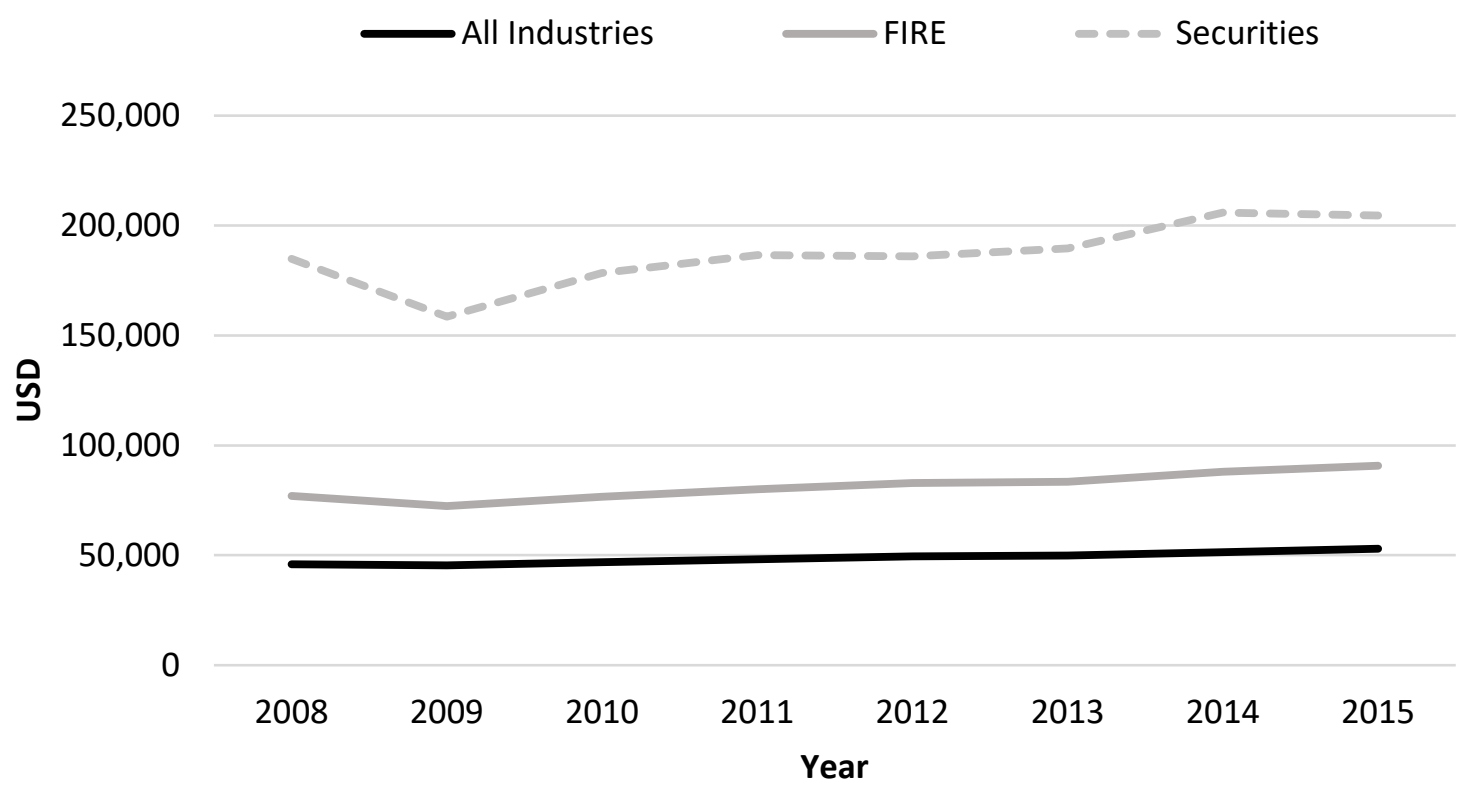

Fig. 3. Average annual payroll per employee. 

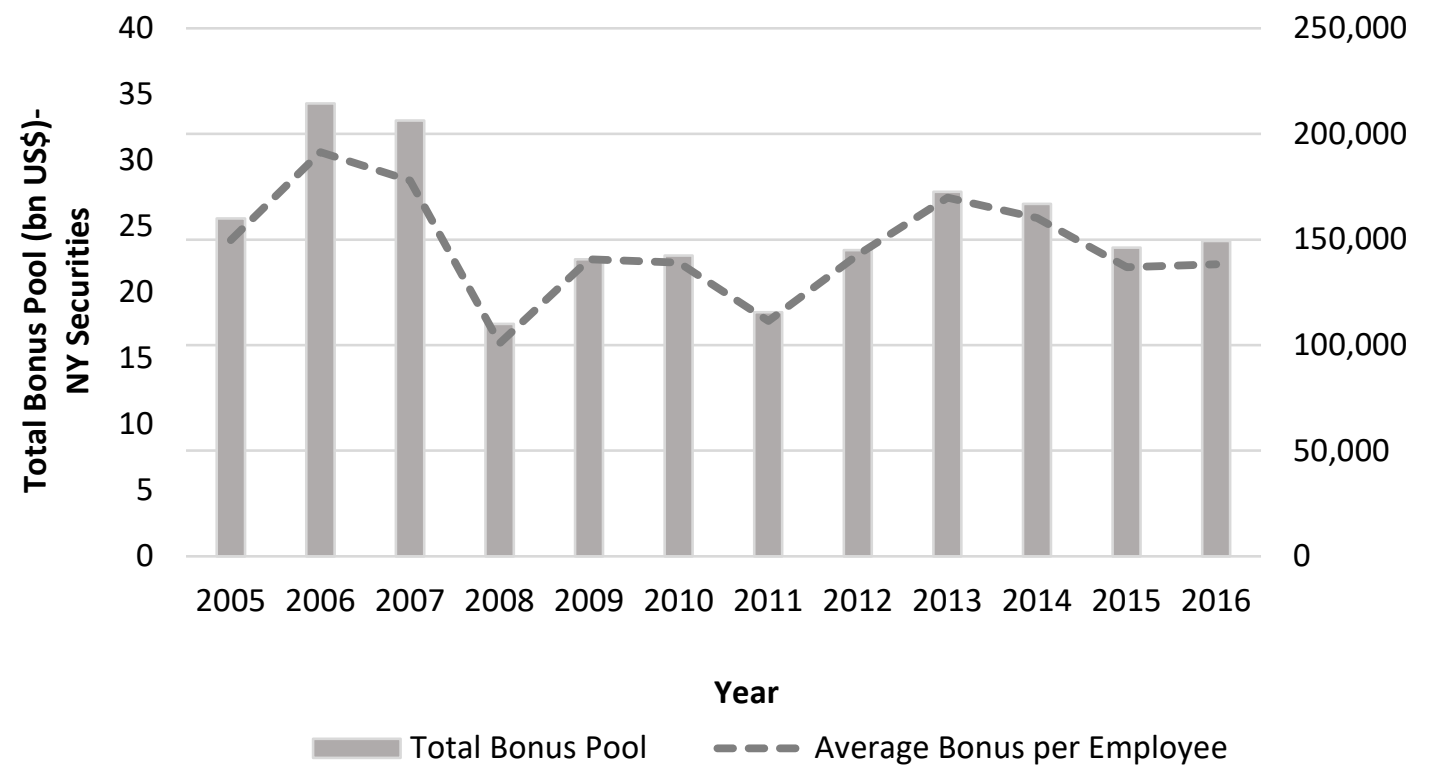

Fig. 4. Total bonus pool and average bonus in the securities industry in New York City Source: Authors based on data from the Office of the New York State Comptroller, 2017.

Salaries and particularly bonuses are distributed extremely unevenly in the securities industry, which means that average remuneration can be a misleading concept, and we need to pay attention to internal hierarchy within firms. A typical career ladder stretches from an analyst position, through associate and vice-president, to the coveted role of a managing director (MD) and finally a partner. With fierce competition, most people who enter the industry leave before they achieve the position of an MD (Ho, 2009). While \$20k may be a big bonus for an analyst, the biggest bonuses in the industry are in tens of millions of USD.

As the crisis hit, job cuts and hire freezes concentrated on the level of analysts, associates and VPs. Firms would be reluctant to lay off MDs, as they represent the core human capital. They lead deals and have direct, often long-term, relationships with clients. These are the people who are supposed to maintain the business, however depressed it may be, and bring back demand for services once the markets rebound. To be sure, MDs, not to mention partners, are the people who decide on layoffs, and after 2008 their reasons to stay put where they were grew stronger, with the value of their nest-eggs (including corporate shares) below what they had expected based on pre-crisis markets, and few attractive employment options in the rest of the financial sector. Instead, the common strategy adopted by securities firms was to reduce the number of junior employees, make the remaining ones work harder, and replace some of them with cheaper back-office employees in US and foreign locations. A similar observation was made by Dawley et al. (2014) in the case study of Northern Rock, where clerical workers suffered largest losses after 2008 in percentage terms, with managerial jobs relatively unscathed. As a result, what may be behind a stable average pay in real terms, is a remuneration structure in which employees at all levels are paid a bit less, but senior employees constitute a larger share of total employment, driving the average payroll up. Put differently, an average employee of the 
industry may now be older and more experienced than on the eve of the crisis. Unfortunately, we have no hard data to verify this hypothesis.

Reasons for continued high pay in the US securities industry may include the following. Firstly, in contrast to the EU, which introduced a cap on bankers' bonuses, in the US the only related regulation was for banks rescued by the government. This stated that compensation above $\$ 500 k$ could only be paid in stock, and was lifted once a bank paid back the government funds, which in most cases happened shortly after 2008. The lack of any further regulation of pay is no doubt a reflection of the strong US securities industry lobby (Wright, 2014). Secondly, the US the securities industry faces fierce competition for talent with highly lucrative high-technology industry. As an illustration of the competition between Wall Street and Silicon Valley consider that Uber is also known as 'Goldman West', because of the large number of former bankers it employs (The Economist, 2015). Thirdly, there are good reasons to think that faced by the necessity of cost-cutting, high remuneration is the last thing securities industry managers would give up. Firms representing the bulk of the industry are no longer partnerships. As the crisis proved, stock options are a poor way of linking the incentives of executives to the long-term performance of their companies. With growing employee turnover, employer loyalty in the securities industry has been low for a long time, but with fundamental uncertainty facing the industry now, we might even expect a degree of 'sinking ship' mentality, which encourages short-term opportunistic behavior and runs counter to moderating pay in the name of long-term responsibility.

\section{Sub-sectoral patterns: the rise of the buy-side}

The sell-side vs. buy-side distinction is important for understanding the post-crisis change in the securities industry. For the sake of our analysis, we define sell-side as NAICS category 5231 (securities and commodity contracts intermediation and brokerage). Buy-side is defined as the sum of funds, trusts and other financial vehicles (525) and other financial investment activities (5239). The sum of the sell- and buy-side is slightly smaller than the total for the securities industry, because the latter also includes securities and commodity exchanges (5232) which function at the intersection of the sell- and buy-side. Category 5232 however accounts for less than $1 \%$ of the total employment and payroll of the securities industry, and its exclusion has no material impact on the results of this section.

As table 1 showed, buy-side has been less sensitive to the crisis and has recovered from it much better than the sell-side. Buy-side now employs more people than the sell-side. In addition, payroll on the buy-side has risen much faster than employment, lifting average annual pay from less than $\$ 160 k$ to $\$ 193 k$, narrowing the gap with sell-side from $\$ 49 k$ to \$25k (figure 5). 


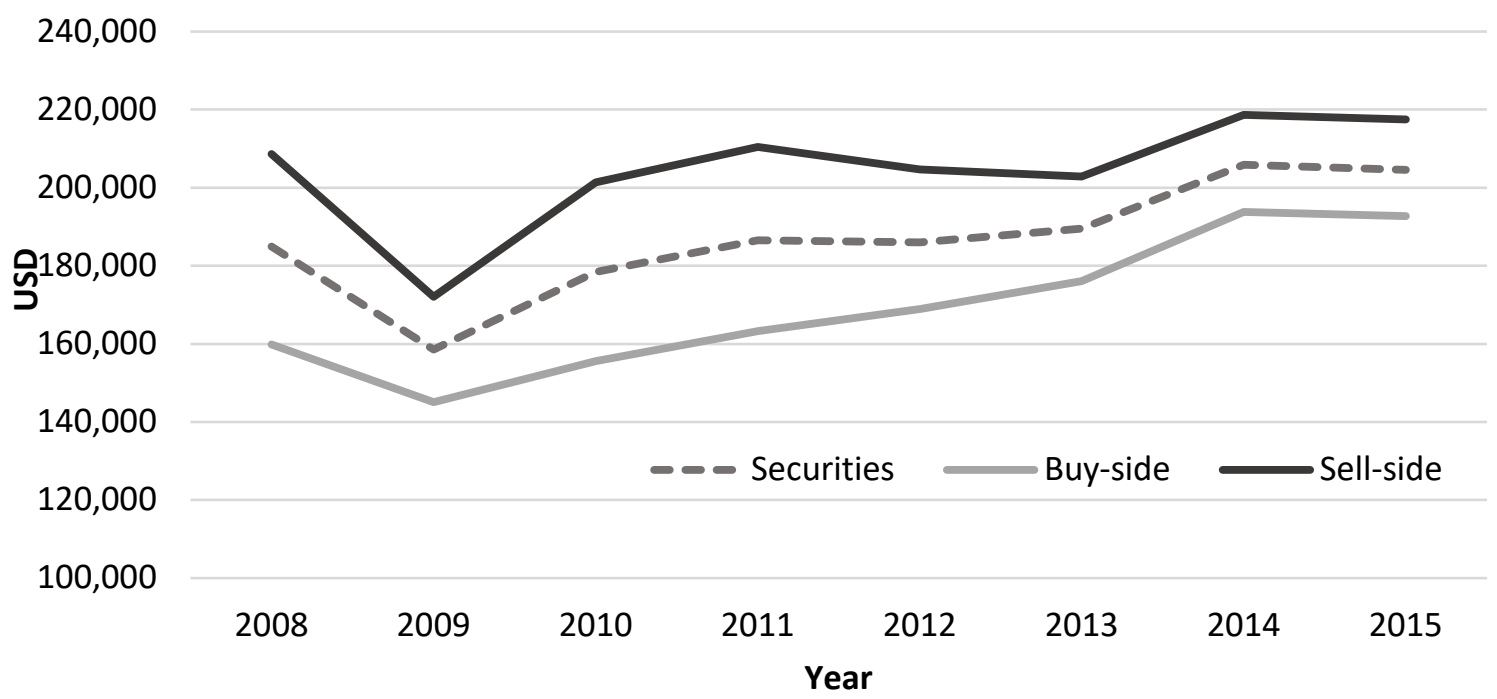

Fig. 5. Average annual payroll per employee.

A simplistic understanding of the terms sell- and buy-side might lead to thinking that they are two sides of the same coin, and both are driven by the ups and downs of the securities markets. The reality is more complicated in ways that help to explain divergence in the resilience of the two subsectors. A major source of revenues on the sell-side, particularly in the run-up to the crisis, has been proprietary trading, with investment banks in the lead trading on their own account rather than on behalf of their customers. This activity has been limited by new regulation in the form of Volcker Rule (Whitehead, 2011). New regulation of the securities industry has focused almost exclusively on the sell-side. Lower demand and higher uncertainty in the global economy also lowers corporate appetite for issuing new securities to fund investment, which directly affects demand for investment banking services. Meanwhile, demand for the services of the buy-side remains strong, underpinned i.a. by growing numbers of the super-rich, and the continuing shift to funded pension systems, as a response to population ageing. This is part and parcel of a general imbalance in the world economy between a glut of savings and inadequate investment in the real economy (Pettis, 2013). While total fees from investment banking activities globally declined significantly since 2008, total assets managed by the world's top 500 asset managers grew (Wójcik et al., 2018; Haberly et al., 2018).

The rise of the buy-side may be interpreted as a case of changing ecosystem dynamics in the securities industry. 'Sell the sell-side, buy the buy-side' has become one of the buzzwords of the securities industry. The authors have seen finance professionals advising oxford graduates, for many of whom investment banking used to be the dream career, to forget about banks and look for jobs with asset managers. There is almost a degree of stigma associated now with working for investment banks. Asset managers have not suffered such reputational issues. They present themselves as progressive institutions addressing real world problems, e.g. by helping ageing populations save for retirement or developing ideas and practices for long-term sustainable investment. Leaders of the asset management industry, such as Larry Fink, the CEO of Blackrock, can often be seen with politicians and giving keynotes at conferences, such Davos World Economic Forum, while the bosses of investment banks seem to try to keep a low profile. 
The rise of the buy-side may be seen as a welcome sign of rebalancing within the securities industry. Investment banks help invent and sell securities, and as such are very much interested in their quantity, trading volumes, and an active market for corporate control, which generates commissions on mergers \& acquisitions advisory services. While asset managers also need a wide array of securities to invest in and liquid financial markets to trade in and out of their portfolios, they tend to make money as a percentage of returns made for the clients, i.e. individual and institutional investors, including pension funds. As such they are more interested in the quality than the quantity of securities, even if this quality is measured from a much more short-term perspective than desirable. The rise of the buy-side may therefore be good news for investors as clients of the securities industry.

On the other hand, the division between sell- and buy-side should not be exaggerated. There are complementarities between buy and sell-side and economies of scale in running both operations through the same company. Since 2008, investment banks have worked hard and often successfully to develop their asset management divisions. While no investment bank is in the top 5 asset management firms globally, JPMorgan, Goldman Sachs, Deutsche Bank, BNP Paribas, and UBS manage over \$1tn each and continue growing (Willis Towers Watson, 2016).

In addition, resilience of both sides of the industry, particularly in terms of employment, has been affected by technology. The central function of the securities industry involves matching issuers with investors on primary markets, when new securities are issued, as well as on secondary markets, where securities are traded (Wójcik, 2011). With new technology, however, these functions can be performed, at least partly, by computers and Internet. In primary markets this can take the form of crowdfunding, whereby entrepreneurs obtain capital directly from investors through online platforms, and Internet IPOs (initial public offerings) where shares of a company are distributed to investors directly via Internet. In secondary markets, computer algorithms are used to conduct trading of securities with minimal human intervention. Majority of stock trading in the US takes this form. At the same time, investment advisory services are being computerized with the introduction of robo-advisors, and passive investment strategies, using technology to mimic market performance, grow at the expense of more labour-intensive active strategies. These and other technologies that transform financial services, often referred to as fintech, have in recent years attracted a lot of attention and investment (Langley and Leyshon, 2017). A subgroup of fintech, called regtech, focuses on the automation and digitization of monitoring, reporting and compliance functions.

For the securities industry, technological change results in increasing capital intensity, with labour being replaced with capital necessary to pay for improvements in technology. In a sense, this is a continuation of the process that started at least with the introduction of the first computers in the industry, and enhanced economies of scale and scope (Clark, 2002). Fintech, however, is distinctive, as it is led by new companies operating at the intersection of the financial and technology industry rather than by established financial firms. The crisis created conditions for the rise of fintech as it made the established financial sector more vulnerable to competition from technology firms and new start-ups. Securities firms on both sides can use fintech to improve their resilience through innovation and upgrading, reducing 
costs and generating new services and markets, but at the same time fintech represents a major source of competition and disruption.

\section{Spatial patterns of resistance and recovery}

Figure 6 presents the pattern of resistance and recovery in the US securities industry employment across states. Resistance is measured with a sensitivity index, in the same way as in table 1. States above the line indicating the index value of 1 are those where securities industry employment between Q4 2008 and Q2 2010 declined more than the overall US employment. Recovery is measured as the percentage change in employment between Q2 2010 and Q1 2016. Further details are presented in appendix 1. At the first glance there seems to be a positive relationship between sensitivity and recovery, but on further inspection the relationship is weak and statistically insignificant. We find states in all quadrants of the graph. States including North Dakota, Nebraska and Delaware exhibited strong resistance and strong post-crisis growth. Alaska, Virginia and District of Columbia witnessed strong resistance in the first instance, followed by decline instead of recovery. New Jersey and Massachusetts exhibited the worst combination of high sensitivity compounded by post-crisis decline. Finally, North Carolina and Louisiana among many others saw high sensitivity followed by recovery.

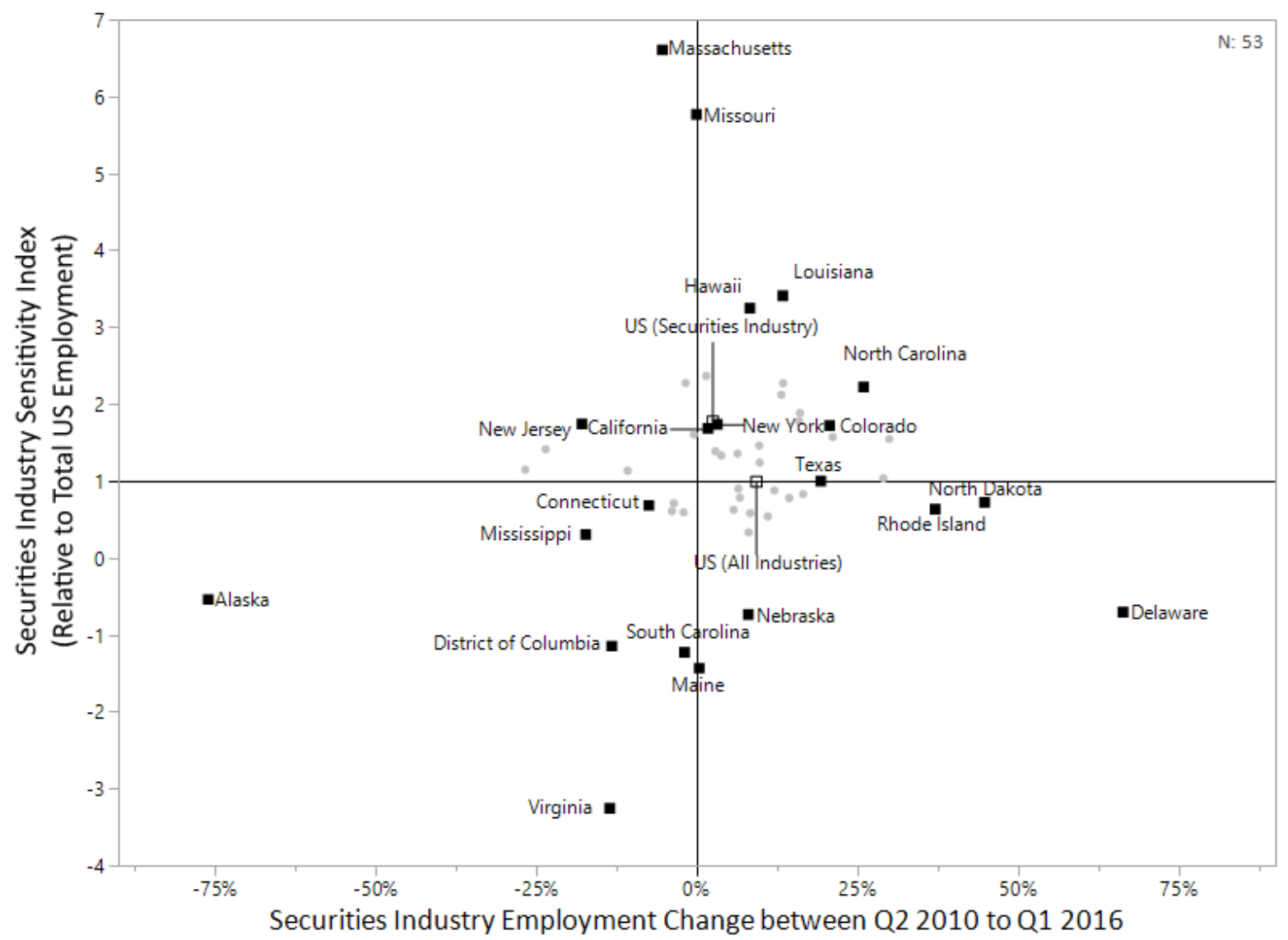

Fig. 6. State level securities industry sensitivity and recovery relative to total US employment.

Delaware is well-known as the hub of corporate law, where an absolute majority of large US companies are incorporated. The resilience of its securities industry may be associated with 
the growing significance of legal functions of securities firms, including regulatory compliance. In states like North Dakota and Texas the strong performance of the securities industry can be associated with the relatively buoyant regional economies. States like Utah, Arizona, North Carolina, Nebraska and lowa, are also likely to have benefited from US banks optimizing their value chains and moving back- and mid-office functions to lower-cost locations within the US. Salt Lake City, for example, hosts an office of Goldman Sachs employing several thousand people (Hoyt, 2013).

The uneven spatial pattern of resilience is also evident at the metropolitan level. Figure 7 shows resistance and recovery for top ten MSAs in terms of securities industry employment in Q1 2016, with the exception of Boston for which data on Q4 2008 and Q2 2010 was not available. Table 2 complements figure 7 with figures on employment in Q1 2008 and Q1 2016, and includes Boston. Securities industry employment in cities less affected by the real estate boom and bust (Chicago, Minneapolis, Houston and Dallas) exhibited more resistance than those that were the main centres of the boom and bust (including Los Angeles, San Francisco, Miami, New York, Boston and Philadelphia). Houston and Dallas, in the buoyant Texan economy, showed strongest recovery. New York, the centre of not only the US, but the global securities industry lost over 43,000 (16\%) of jobs in the industry at the MSA level between Q1 2008 and Q1 2016. In absolute terms the losses were divided equally between Manhattan and the rest of the MSA, but in percentage terms Manhattan lost $11 \%$ of its securities industry jobs, while the rest of the MSA $32 \%$.

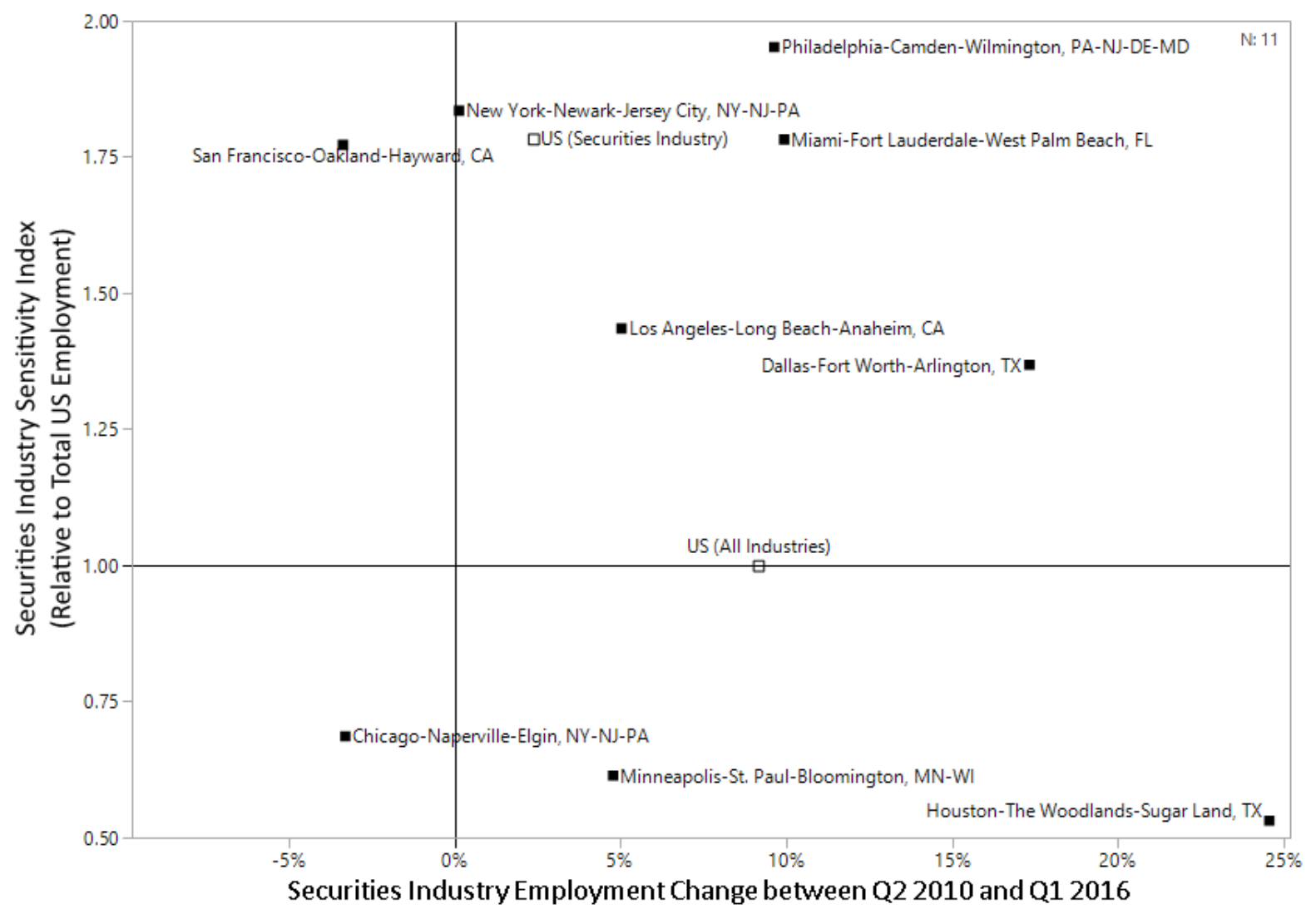

Fig. 7. Top MSAs securities industry sensitivity and recovery relative to US employment.

Table 2. Top 10 securities industry centres in Q1 2016.

Source: Authors based on data from US Census and County Business Patterns. 


\begin{tabular}{|c|c|c|c|c|}
\hline \multirow[b]{2}{*}{ MSA } & \multicolumn{4}{|c|}{ Securities Industry Employment } \\
\hline & Q1 2008 & Q1 2016 & $\begin{array}{l}\text { Absolute } \\
\text { Change }\end{array}$ & \% Change \\
\hline $\begin{array}{l}\text { New York-Newark-Jersey } \\
\text { City, NY-NJ-PA }\end{array}$ & 268,105 & 224,874 & $-43,231$ & $-16.12 \%$ \\
\hline $\begin{array}{l}\text { Manhattan (New York } \\
\text { County) }\end{array}$ & 199,352 & 178,030 & $-21,322$ & $-10.70 \%$ \\
\hline $\begin{array}{l}\text { Chicago-Naperville-Elgin, IL- } \\
\text { IN-WI }\end{array}$ & 51,194 & 47,283 & $-3,911$ & $-7.64 \%$ \\
\hline $\begin{array}{l}\text { Boston-Cambridge-Newton, } \\
\text { MA-NH }\end{array}$ & 68,317 & 42,193 & $-26,124$ & $-38.24 \%$ \\
\hline $\begin{array}{l}\text { Los Angeles-Long Beach- } \\
\text { Anaheim, CA }\end{array}$ & 40,283 & 39,413 & -870 & $-2.16 \%$ \\
\hline $\begin{array}{l}\text { Philadelphia-Camden- } \\
\text { Wilmington, PA-NJ-DE-MD }\end{array}$ & 35,694 & 36,501 & 807 & $2.26 \%$ \\
\hline $\begin{array}{l}\text { San Francisco-Oakland- } \\
\text { Hayward, CA }\end{array}$ & 29,810 & 28,499 & $-1,311$ & $-4.40 \%$ \\
\hline $\begin{array}{l}\text { Dallas-Fort Worth- } \\
\text { Arlington, TX }\end{array}$ & 24,021 & 27,181 & 3,160 & $13.16 \%$ \\
\hline $\begin{array}{l}\text { Houston-The Woodlands- } \\
\text { Sugar Land, TX }\end{array}$ & 16,368 & 20,032 & 3,664 & $22.39 \%$ \\
\hline $\begin{array}{l}\text { Miami-Fort Lauderdale- } \\
\text { West Palm Beach, FL }\end{array}$ & 19,685 & 19,633 & -52 & $-0.26 \%$ \\
\hline $\begin{array}{l}\text { Minneapolis-St. Paul- } \\
\text { Bloomington, MN-WI }\end{array}$ & 18,369 & 18,843 & 474 & $2.58 \%$ \\
\hline
\end{tabular}

The ranking of the largest US securities industry centres in terms of employment remained remarkably stable. The only change in the top 10 between 2008 and 2016 was the replacement of Bridgeport-Stamford-Norwalk MSA in Connecticut, the hub of hedge fund industry, ranked $8^{\text {th }}$ at the start of 2008, with Houston. As figure 8 demonstrates, however, employment in the US securities industry has become less spatially concentrated. The decline of employment in New York was a major contributor to the process, but so were declines in other leading centres including Boston and Chicago. The pattern of spatial dispersion of employment is confirmed by state-level data. Measured with the following conventional index, it fell from 0.0334 to 0.0265 .

$C=\sum_{i=1}^{N}\left(x_{i}-s_{i}\right)^{2}$

where $\mathrm{i}$ is state; $\mathrm{N}$ is the total number of states; $\mathrm{x}$ is the fraction share of securities industry employment of a state in the US securities industry employment; and $\mathrm{s}$ is the fraction share of total employment of a state in total US employment. This contrasts with increasing concentration since 2008 in credit banking and insurance, and research showing that in the UK, for example, geographical concentration of the financial sector has increased significantly since 2008 (Wójcik and MacDonald-Korth, 2015). This suggests, that in contrast to insurance and particularly credit banking, restructuring in the US securities industry has focused on cuts in headquarter locations and large firms, often overstretched in global markets, and not on cutting regional and local offices and branches or bankruptcies of small regional and local firms. 


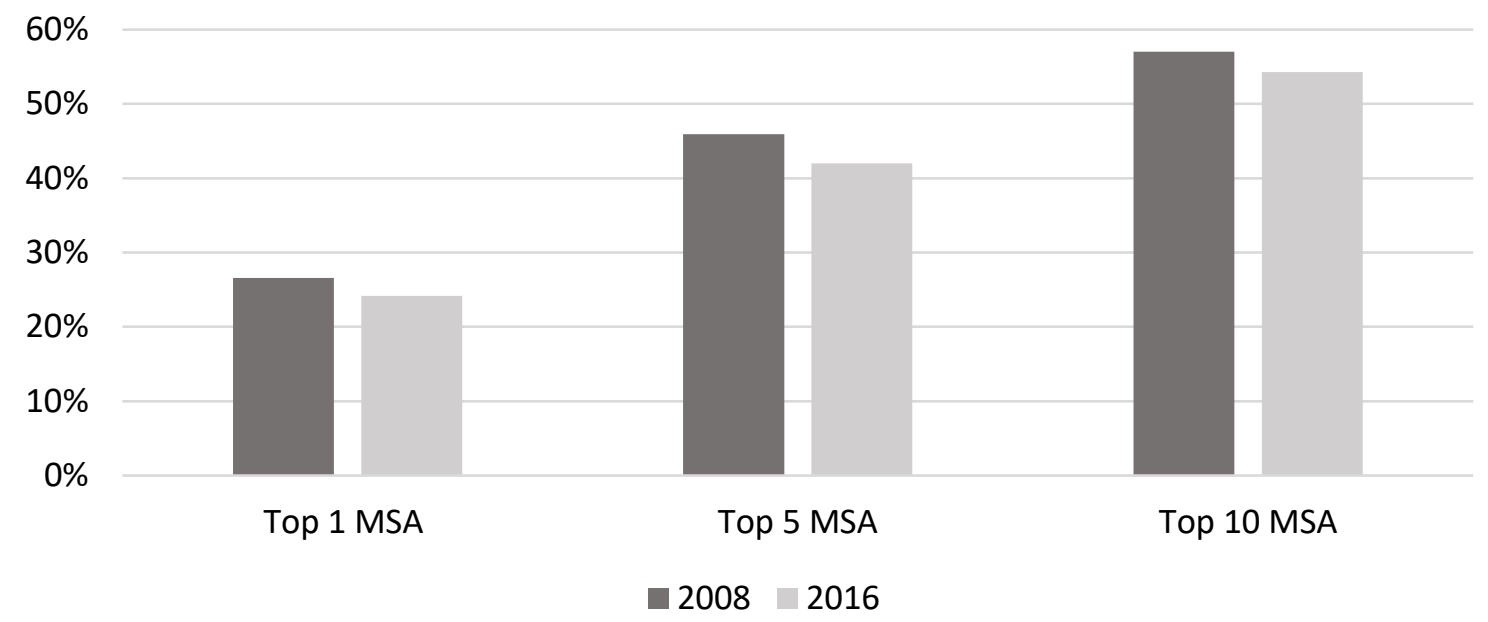

Fig. 8. Share of top 1,5 and 10 MSAs in total US securities industry employment in Q1 2008 and Q1 2016.

\section{Whose resilience? persistent gender inequality}

It is well-documented that the securities industry, and investment banking in particular, is a male-dominated industry (Ho, 2009; McDowell, 1997; Tett 2009). The male-dominance is particularly strong at higher levels of organization and on trading floors, with accounting, human resources and legal departments, as well as clerical functions employing more women. Recent research also shows that gender inequality in investment banking often starts with MBA education (Hall and Appleyard, 2012). Gender inequality, and more general lack of diversity, has been criticized for encouraging group-think, herd behavior and excessive risk-taking, key cultural factors that contributed to the crisis (McDowell, 2010). In this context, it is important to compare the patterns of resilience in the securities industry between female and male employment.

As figure 9 shows, on the sell-side, the number of female as percentage of male employees has been remarkably stable at $66 \%$, with women representing $40 \%$ of total employment. The number of male and female employees both declined by approximately $15 \%$. On the buy-side women were better represented, but the ratio has actually deteriorated significantly over time, from women accounting for over $95 \%$ of men to just above $80 \%$. Between the beginning of 2008 and start of 2016 the number of women employed in asset management fell by $7 \%$, while the number of men increased by $8 \%$, leading to a small overall increase in employment. This replacement of women with men could have been affected by the application of new technologies allowing downzising and offshoring of backand mid-office functions, where most women working in asset management have traditionally been employed, and so concentrated in the lower status and lower paid parts of the industry. 


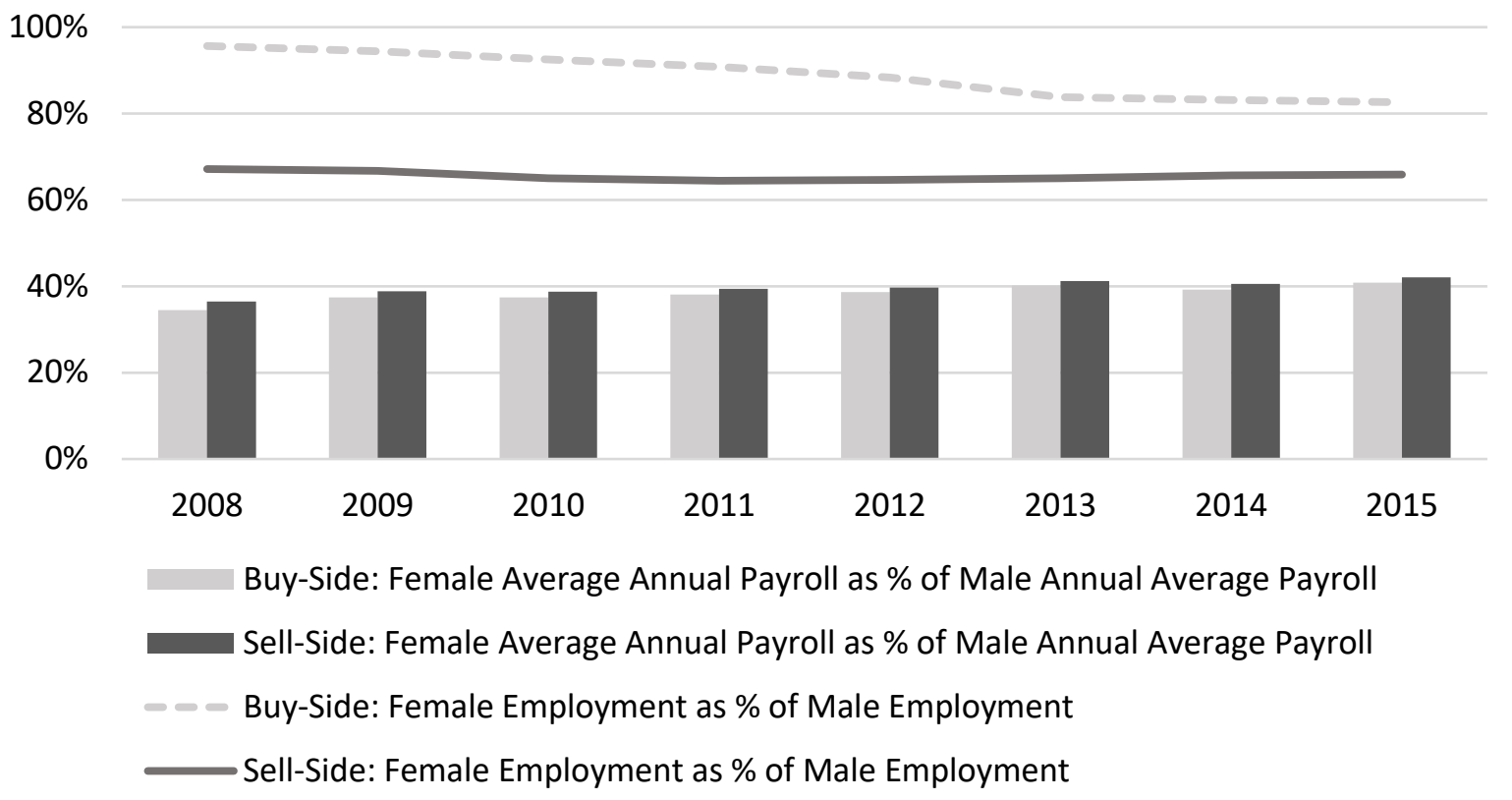

Fig. 9. Relationship between female and male employment and payroll in the securities industry

With an overwhelming share of women in securities industry employed in more junior, lesser paid and clerical positions, women were more vulnerable to layoffs, with the latter managed predominantly by men. In the wake of the 2008 crisis, numerous lawsuits have been brought against major financial services firms. Morgan Stanley, Wells Fargo, Bank of America, Citigroup and others, all settled gender discrimination lawsuits, related to both pay differences and harassment, by paying tens of millions of dollars each (Trillium, 2016). The preponderance of gender discrimination cases at investment banks suggests that the net percentage decline in the number of men and women employed in sell-side may be comparable not because women were treated equally during layoffs, but because many women have been hired by growing compliance departments, thus offsetting large numbers of women laid off in other divisions.

In terms of payroll, the situation of women in the securities industry has improved only slightly. While in 2008 average annual payroll per female employee represented approximately $35 \%$ of male pay, by 2015 it rose to $41 \%$. Throughout the 2008-15 period, women in investment banking were paid marginally less unequally than in asset management. Unfortunately, we do not have data to compare male and female pay at different levels of organizational hierarchy. It is possible that some of the improvement in average female pay, small as it is, is driven by men replacing women in hitherto female dominated back- and mid-office functions, as well as in junior positions, most of which require increasingly technical skills, often seen as a masculine attribute, to take advantage of the new technologies.

To further analyze the position of women in the securities industry, we focused on the five largest investment banks and five largest asset management companies in the US that have publicly available annual reports, and compared the number of women on the boards of directors between 2008 and 2016. It is worth noting that due to the dominance of the US in the securities industry, all the companies in table 2 feature among the ten largest 
investment banks and asset managers in the world. In 2008 only 11 out of 68 directors of investment banks and 12 out of 66 directors of asset managers were women. The highest percentage of women featured on the board of State Street Global Advisors (33\%), while the Blackrock had 1 women director out of 16 in 2008. By 2016 the representation of women improved only slightly, to 16 out of 67 directors on the sell-side, and 15 out of 70 on the buy-side. Citigroup and Bank of America Merrill Lynch had the most gender diverse boards, with 6 out of 17, and 4 out of 14 female members, respectively. Only four out of ten companies in our sample increased the number of female directors, two on the sell-side and two on the buy-side.

\begin{tabular}{llll}
\hline Company & Institution Type & $\mathbf{2 0 1 6}$ & $\mathbf{2 0 0 8}$ \\
\hline Goldman Sachs & Bank & 2 out of 11 & 2 out of 11 \\
Morgan Stanley & Bank & 2 out of 13 & 1 out of 12 \\
JP Morgan & Bank & 2 out of 12 & 2 out of 11 \\
Citigroup & Bank & 6 out of 17 & 2 out of 15 \\
Bank of America Merril Lynch & Bank & 4 out of 14 & 4 out of 19 \\
Blackrock & Asset manager & 4 out of 19 & 1 out of 16 \\
Vanguard Group & Asset manager & 2 out of 10 & 2 out of 9 \\
State Street Global Advisors & Asset manager & 3 out of 11 & 4 out of 12 \\
Prudential Financial & Asset manager & 4 out of 16 & 3 out of 15 \\
Northern Trust Asset Management & Asset manager & 2 out of 14 & 2 out of 14 \\
\hline
\end{tabular}

Table 3: Women on the board of directors of the 5 largest investment banks and asset managers.

Source: Authors based on annual reports from individual companies.

Our evidence of persistent gender inequality in the US securities industry is consistent with that found in other sources. The Oliver Wyman report on Women in Financial Services demonstrates that in the US, only $20 \%$ of executive committee members in financial services were women, compared to the global average of $16 \%$. The report concludes its analysis at the global level stating that "Female representation is growing on financial services Boards and Executive Committees, but progress is slow. At current rates of growth, financial services globally will not reach even $30 \%$ female Executive Committee representation until 2048" $(2016,6)$. On the buy-side, a recent analysis by Morningstar finds that fewer than $10 \%$ of all US fund managers are women, and funds managed by women account for less than $2 \%$ of total assets under management, compared to $74 \%$ of assets in funds managed by men only, and $24 \%$ managed by women and men. Gender inequality in the securities industry and its absence from the agenda of most firms reflects a more general lack of diversity in terms of ethnicity, race, and socio-economic class. There has been no significant government regulation to improve diversity in the financial sector. Focus on 'purely' financial issues, such as capital requirements and trading, have pushed concerns about diversity to the background. In May 2016, Bloomberg launched the first of its kind Financial Services Gender-Equality Index, based on data on corporate gender statistics, employee policies, gender-conscious product offerings and external community support and engagement. 26 companies submitted information to join the index at its inauguration, including many universal banks and several asset managers, but not a single 'pure' investment bank (Bloomberg, 2016). 


\section{Conclusions and implications}

The goal of the paper was to investigate the resilience of the US securities industry to the GFC and the evolution of the industry between 2008 and 2016, with focus on employment, location, remuneration, sell-side versus buy-side dynamics, and gender. We approached the question of resilience by recognizing its political and cultural economy dimensions, including regulation and gender relations. Our results show that the US securities industry has suffered significant losses in terms of employment and its recovery has been slow. Under the pressures of depressed demand, new regulation and cost cutting, the industry has gone through significant adaptation in terms of corporate reorganisation, value chain optimisation, market reorientation and innovation, but has not yet adapted in terms of remuneration. Buy-side of the industry has performed much better than sell-side in terms of resistance and recovery. The patterns of resistance and recovery have been highly uneven across states and cities. While the top of the hierarchy of securities industry centres has not changed significantly in terms of ranking, large centres, with New York in the lead, have suffered larger job losses than smaller centres, reflecting a significant spatial dispersion of employment in the industry. Male employment has proven more resilient than female employment highlighting continued gender inequality and lack of diversity.

To reflect on the broader implications of our findings, imagine that we can go back in time to late 2008 and ask people how they expect the securities industry to change after the crisis. We suspect that most people would expect a downsized securities industry, and one focused more on the quality rather than the volume of its activity, serving the rest of the economy and society rather than serving itself (Kay, 2015). In other words, there were expectations of high sensitivity of the industry to the shock and hopes for a major and positive adaptation. Some observers even predicted investment banks, as key players in the securities industry, to become extinct (Ferguson, 2008).

Our results suggest that, in reality, change in the securities industry has fallen short of such expectations. Downsizing in terms of employment has been significant but far from dramatic. Adaptation has taken place in some respects but not others. The rise of the buyside, for example, may represent positive change, a re-balancing of power, away from the part of the industry obsessed with the quantity, volume and trading of securities to one with more incentives to care about the quality of financial instruments in the interest of its beneficiaries, savers who invest in financial markets to pay for their future consumption, health care, retirement and other needs. The literature on the rise of institutional investors, including pension funds, was well established before 2008, but arguably it took the global financial crisis to potentially catalyse a shift away from investment bank capitalism (Clark, 2000; Clark, Dixon and Monk, 2013). On the other hand, though, it may be a reflection of global economic imbalances between a rising glut of savings and dwindling investment. In addition, average pay in the securities industry has hardly declined in real terms, and remains out of touch with the rest of the US economy. Through lobbying against financial reforms, keeping retained profits available to shareholders to a minimum, and through internal restructuring, the industry has done what it could to protect the high level of remuneration. Analysis by gender showed that the share of women in the securities 
industry employment has fallen, while their remuneration and representation in corporate decision-making have improved only marginally.

Shrinkage, dispersion of employment, and the rise of the buy-side are all important, but persistent levels of pay and gender inequality indicate that culture in the industry has not really changed yet. Culture, including its corporate variety, typically takes long to change, but the fact that the industry has changed so little in important respects for nearly a decade since the crisis must be disappointing and requires further research. Is it possible that the blow of the crisis is still working its way through financial institutions, and we need to give them more time to change or is intervention from outside needed to enforce change?

Another direction for future research would be to compare resilience in the securities industry, or financial sector as a whole, between the USA and other countries and regions. Some industry experts claim that European financial institutions have introduced more fundamental reforms than their US counterparts. Andrew Bailey, CEO of Financial Conduct Authority in the UK, was reported to say that "while European banks were making good progress on culture and particularly on issues such as compensation, US banks were lagging behind" (Wighton, 2016). The French leader of investment banking, Societe Generale, recently appointed a Head for Culture and Conduct, while Barclays have an MD in charge of reputation and citizenship. A quick search on Google seems to find no such positions in US banks. Other initiatives are underway. For example, the UK's Senior Managers and Certification Regime introduced in 2016 by the Financial Conduct Authority requires information on senior managers' performance, their credit history, and misconduct for the last 6 years. A Banking Standards Board was created in the UK in 2015 to focus on professional standards and behavior. On the other hand, women account for only $17 \%$ of executive committee membership in the UK, compared to $20 \%$ in the US (Oliver Wyman, 2016).

Whatever we might have expected in 2008, reform in the securities industry, at the apex of the financial sector, remains an unfinished business. Let us end by illustrating this point with recent events in the heart of the securities industry. On the $7^{\text {th }}$ of March 2017, State Street Global Advisors, the asset management business of State Street Corporation, installed a bronze statue of a determined-looking young Latina girl in Lower Manhattan, staring down the sculpture of the Charging Bull - a long-standing symbol of Wall Street (Friedman, 2017). The Fearless Girl, as it was called, quickly struck a chord With New Yorkers and tourists alike, and generated \$millions worth of free publicity for State Street. The Fearless Girl symbolizes the challenge to the lack of diversity in the securities industry, but given the identity of its sponsor it may also be seen to represent a challenge of buy-side to the sell-side, and a general challenge to 'investment bank capitalism'.

Originally, the Fearless Girl was to be displayed near Wall Street for only a month. In late March 2017 Mayor of New York Bill de Blasio announced that it would remain in place for another year. As of February 2018, there were rumors that both the Fearless Girl and her counterpart, the Charging Bull may be moved to more pedestrian-friendly location. This is good news. In our opinion, it will take much longer and much more staring down by everyone, including geographers, before Wall Street, and with it the global financial industry 
moves anywhere near an acceptable level of reform. Geographers have much to contribute to this debate and this cause. 


\section{References}

Bayoumi, T., 2017. Unfinished Business: The Unexplored Causes of the Financial Crisis and the Lessons Yet to be Learned. Yale University Press, New Haven.

Bloomberg, 2016. Bloomberg Launches Financial Services Gender-Equality Index. 3 May, https://www.bloomberg.com/company/announcements/bloomberg-launches-financialservices-gender-equality-index/.

Boschma, R., 2015. Towards an evolutionary perspective on regional resilience. Regional Studies, 49(5), 733-751.

Boschma, R., Frenken, K. 2006. Why is economic geography not an evolutionary science?

Towards an evolutionary economic geography. Journal of Economic Geography, 6, 273-302.

Clark, G.L., 2002. London in the European financial services industry: locational advantage and product complementarities. Journal of Economic Geography 2 (4), 433-453.

Clark, G.L., 2000. Pension Fund Capitalism. Oxford University Press, Oxford.

Clark, G.L., Dixon, A. and Monk, A., 2013. Sovereign Wealth Funds: Legitimacy, Governance, and Global Power. Princeton University Press, Princeton.

Dawley, S., Marshall, N., Pike, A., Pollard, J. and Tomaney, J., 2014. Continuity and evolution in an old industrial region: the labour market dynamics of the rise and fall of Northern Rock. Regional Studies, 48(1), 154-172.

Ferguson N. 2008. The Ascent of Money: A Financial History of the World. New York:Penguin.

Financial Times, 2017a. More than one in 10 staff at US banks work in Asia. 26 February, https://www.ft.com/content/7c99c39a-f73d-11e6-9516-2d969e0d3b65.

Financial Times, 2015. Poland draws big banks for 'nearsourcing'. 22 January, https://www.ft.com/content/1df9e49c-a153-11e4-8d19-00144feab7de

Friedman, Z., 2017. This fearless girl may change the face of Wall Street. Forbes, 8 March, https://www.forbes.com/sites/zackfriedman/2017/03/08/state-street-bronzestatue/\#7397ab703072.

Fromhold-Eisebith, M., 2015. Sectoral resilience: Conceptualizing industry-specific spatial patterns of interactive crisis adjustment. European Planning Studies, 23(9), 1675-1694.

Goldin, I and Mariathasan, M. 2014. The Butterfly Defect: How Globalization Creates systemic Risks, and What to Do about It. Princeton University Press, Princeton.

Grote, M.H. and Täube, F.A., 2006. Offshoring the financial services industry: implications for the evolution of Indian IT clusters. Environment and Planning A 38, 1287-1305.

Haberly, D., MacDonald-Korth, D., Urban, M., Wójcik, D. 2018. Politics and technology in Global Financial Networks: evolution of asset management industry 2006-16. Mansucript.

Hall, S. and Aplleyard, L., 2012. Financial business education: the remaking of gendered investment banking subjects in the (post-crisis) City of London. Journal of Cultural Economy $5(4), 457-472$. 
Helleiner, E., 2014. The Status Quo: Global Financial Governnance After the 2008 Meltdown. Cornell University Press, Ithaca, NY.

Ho, K., 2009. Liquidated: An Ethnography of Wall Street. Duke University Press, Durham NC. Hoyt, J., 2013. The Committee for Better Banks Report: The state of the bank employee on Wall Street. Available at: http://betterbanks.org/wp-content/uploads/2013/12/BankWorker-Campaign-Report-.pdf

Huffington Post, 2011. Goldman Sachs Plans To Hire 1,000 In Singapore While Cutting U.S. Jobs. 27 August, http://www.huffingtonpost.com/2011/06/27/goldman-sachs-outsourcessingapore $\mathrm{n}$ 885549.html.

Johnson S. and J. Kwak. 2010. 13 Bankers: Wall Street Takeover and the Next Financial Meltdown. New York: Pantheon.

Kay, J. 2015. Other People's Money: Masters of the Universe or Servants of the People? Profile Books, London.

Langley, P. and Leyshon, A., 2017. Capitalizing on the crowd: the monetary and financial ecologies of crowdfunding. Environment and Planning A 49 (5), 1019-1039.

Martin, R., 2012. Regional economic resilience, hysteresis and recessionary shocks. Journal of Economic Geography, 12(1), 1-32.

Martin, R. and Sunley, P., 2015. On the notion of regional economic resilience: conceptualization and explanation. Journal of Economic Geography, 15(1), 1-42.

Martin, R. and Pollard, J., 2017. Handbook of the Geographies of Money and Finance. Edward Elgar, London.

Massey, D., 1984. Spatial Divisions of Labour: Social Structures and the Geography of Production. Macmillan, London.

Massini, S. and Miozzo, M., 2012. Outsourcing and offshoring of business services: challenges to theory, management and geography of innovation. Regional Studies 46 (9), 1219-1242.

McDowell, L., 2010. Capital culture revisited: sex, testosterone and the City. International Journal of Urban and Regional Research 34 (3), 652-658.

McDowell, L., 1997. Capital Culture: Gender at Work in the City. Wiley-Blackwell, Oxford.

McGrath, J., McNulty, L. 2014. Compliance rules trigger bonanza for consultants, Financial News, 9 June, 2.

Morrison, A. and Wilhelm, W., 2007. Investment Banking: Institutions, Politics, and Law. Oxford University Press, Oxford.

Oliver Wyman, 2016. Women in Financial Services. Report.

Pettis, M., 2013. The Great Rebalancing: Trade, Conflict and the Perilous Road ahead for the World. Princeton University Press, Princeton.

Philippon, T. and Reshef, A., 2012. Wages and human capital in the US finance industry: 1909-2006. The Quarterly Journal of Economics 127 (4), 1551-1609. 
Reggiani, A., De Graaff, T. and Nijkamp, P., 2002. Resilience: an evolutionary approach to spatial economic systems. Networks and Spatial Economics, 2(2), 211-229.

Reinhart, C. and Rogoff, K. 2009. This Time is Different: Eight Centuries of Financial Folly. Princeton University Press, Princeton.

Reuters, 2016a. Macquarie lays off 15 percent of U.S. investment banking group. 14 April, http://www.reuters.com/article/us-macquarie-uslayoffs-idUSKCNOXA2H9.

Schoenberger, E., 1997. The Cultural Crisis of the Firm. Blackwell, Oxford.

SIFMA, 2017. Securities Industry and Financial Markets Association 2017 FactBook. New York, https://www.sifma.org/wp-content/uploads/2016/10/US-Fact-Book-2017-SIFMA.pdf

Sorkin, A., 2010. Too Big To Fail: The Inside Story of How Wall Street and Washington Fought to Save the Financial System and Themselves. Penguin, New York.

Storper, M. and Scott, A.J., 2009. Rethinking human capital, creativity and urban growth. Journal of economic geography, 9(2), 147-167.

Strange, S., 1986. Casino Capitalism. Blackwell, Oxford.

Tett, G., 2009. Fool's Gold: How Unrestrained Greed Corrupted a Dream, Shattered Global Markets and Unleashed a Catastrophe. Abacus, London.

The Economic Times, 2011. Citi, BofA \& JPMorgan to outsource $\$ 5$ bn of IT and back office projects to India, 14 February,

http://economictimes.indiatimes.com/articleshow/7490712.cms?utm_source=contentofint erest\&utm_medium=text\&utm_campaign=cppst.

The Economist, 2015. To fly, to fall, to fly again. 25 July, http://www.economist.com/news/briefing/21659722-tech-boom-may-get-bumpy-it-willnot-end-repeat-dotcom-crash-fly.The Economist, 2016. The final bill. 11 August, http://www.economist.com/news/finance-and-economics/21704815-legal-storm-

surrounding-banks-largely-over-final-bill.

The New York Times, 2008. Biggest Unit at Morgan Is to Lose $10 \%$ of Staff. 12 November, http://www.nytimes.com/2008/11/13/business/13morgan.html.

Trillium Asset Management, 2016. Citigroup - gender pay disparity - 2016. http://www.trilliuminvest.com/shareholder-proposal/citigroup-gender-pay-disparity-2016/.

Whitehead, C.K. 2011. The Volcker Rule and evolving financial markets. Harvard Business Law Review 1, 39-74.

Wighton, D., 2016. Bankers yearn for 'noble purpose' - largely to serve their own interests, Financial News, 8 February, 7.

Wójcik, D., 2012. The end of investment bank capitalism? An economic geography of financial jobs and power. Economic Geography 88 (4), 345-368.

Wójcik, D., 2011. The Global Stock Market: Issuers, Investors and Intermediaries in an Uneven World. Oxford University Press, Oxford.

Wójcik, D. and MacDonald-Korth, D., 2015. The British and the German financial sectors in the wake of the crisis: size, structure and spatial concentration. Journal of Economic Geography 15 (5), 1033-1054. 
Wójcik, D., 2018. Global Financial Newtorks. In: Clark, G.L., Gertler, M.S., Feldman, M. and Wójcik, D. (Eds), New Oxford Handbook of Economic Geography. Oxford University Press, Oxford, pp. 557-574.

Wójcik, D., Knight, E., O’Neill, P. and Pažitka, V. 2018. Economic geography of investment banking since 2008: the geography of shrinkage and shift. Economic Geography (forthcoming).

Wójcik, D., Camilleri, J., loannou, S. and Pažitka, V. 2018b. Resilience of investment banks to the global financial crisis: the case of Goldman Sachs and Morgan Stanley. Manuscript.

Wright, W., 2016. Taking Stock on Pay. Report by New Financial, London.

Wright, W., 2014. New name, same old thinking on pay. Financial News, 3 February, 13. 
Appendix 1: Securities industry employment, sensitivity and recovery by state

\begin{tabular}{|c|c|c|c|c|}
\hline \multirow{2}{*}{ State } & \multicolumn{2}{|c|}{ SI Employment } & \multicolumn{2}{|c|}{ Sensitivity and Recovery } \\
\hline & Q1 2008 & Q1 2016 & Sensitivity Index & Recovery Index \\
\hline Alabama & 4,403 & 4,162 & 1.39 & 0.32 \\
\hline Alaska & 2,136 & 558 & -0.54 & -8.31 \\
\hline Arizona & 15,178 & 18,650 & 1.55 & 3.27 \\
\hline Arkansas & 3,237 & 2,961 & 1.60 & -0.05 \\
\hline California & 96,000 & 92,014 & 1.68 & 0.19 \\
\hline Colorado & 17,830 & 21,161 & 1.72 & 2.26 \\
\hline Connecticut & 29,477 & 26,526 & 0.68 & -0.82 \\
\hline Delaware & 4,562 & 7,949 & -0.71 & 7.24 \\
\hline District of Columbia & 4,563 & 4,238 & -1.15 & -1.45 \\
\hline Florida & 46,610 & 46,586 & 2.12 & 1.43 \\
\hline Georgia & 16,492 & 16,590 & 0.78 & 0.73 \\
\hline Hawaii & 1,259 & 1,133 & 3.25 & 0.90 \\
\hline Idaho & 2,047 & 2,076 & 1.24 & 1.07 \\
\hline Illinois & 54,501 & 50,506 & 0.71 & -0.39 \\
\hline Indiana & 8,708 & 9,519 & 0.88 & 1.32 \\
\hline lowa & 3,760 & 4,658 & 0.33 & 0.88 \\
\hline Kansas & 5,549 & 5,860 & 2.27 & 1.47 \\
\hline Kentucky & 5,884 & 7,196 & 1.88 & 1.75 \\
\hline Louisiana & 4,439 & 3,895 & 3.41 & 1.46 \\
\hline Maine & 1,425 & 1,367 & -1.44 & 0.04 \\
\hline Maryland & 17,524 & 19,058 & 0.58 & 0.91 \\
\hline Massachusetts & 70,840 & 43,419 & 6.61 & -0.59 \\
\hline Michigan & 12,876 & 12,890 & 0.61 & -0.42 \\
\hline Minnesota & 20,104 & 20,650 & 0.90 & 0.70 \\
\hline Mississippi & 1,649 & 1,335 & 0.30 & -1.89 \\
\hline Missouri & 19,236 & 15,205 & 5.77 & -0.01 \\
\hline Montana & 1,343 & 1,302 & 2.37 & 0.16 \\
\hline Nebraska & 3,738 & 4,723 & -0.74 & 0.87 \\
\hline Nevada & 3,838 & 2,735 & 1.15 & -2.92 \\
\hline New Hampshire & 5,837 & 6,198 & 1.78 & 1.74 \\
\hline New Jersey & 58,636 & 41,647 & 1.74 & -1.95 \\
\hline New Mexico & 1,744 & 1,841 & 0.62 & 0.62 \\
\hline New York & 229,581 & 201,020 & 1.74 & 0.35 \\
\hline North Carolina & 20,001 & 22,431 & 2.22 & 2.83 \\
\hline North Dakota & 808 & 1,226 & 0.72 & 4.89 \\
\hline Ohio & 19,604 & 18,041 & 0.59 & -0.23 \\
\hline Oklahoma & 5,005 & 4,389 & 2.27 & -0.19 \\
\hline Oregon & 5,506 & 5,987 & 0.78 & 1.57 \\
\hline Pennsylvania & 53,716 & 39,555 & 1.41 & -2.57 \\
\hline Rhode Island & 3,646 & 5,504 & 0.63 & 4.05 \\
\hline South Carolina & 5,211 & 4,600 & -1.23 & -0.21 \\
\hline South Dakota & 775 & 991 & 1.03 & 3.17 \\
\hline Tennessee & 9,458 & 10,330 & 0.54 & 1.21 \\
\hline
\end{tabular}




\begin{tabular}{lcccc} 
Texas & 57,934 & 66,993 & 1.00 & 2.11 \\
Utah & 7,619 & 8,402 & 1.57 & 2.31 \\
Vermont & 896 & 745 & 1.13 & -1.18 \\
Virginia & 19,558 & 15,057 & -3.26 & -1.48 \\
Washington & 11,391 & 13,023 & 0.83 & 1.81 \\
West Virginia & 1,034 & 1,027 & 1.36 & 0.69 \\
Wisconsin & 11,417 & 11,220 & 1.33 & 0.41 \\
Wyoming & 496 & 551 & 1.46 & 1.06 \\
US Wide & $1,009,081$ & 929,700 & 1.78 & 0.26 \\
US Wide (All Industries & $130,417,613$ & $135,869,368$ & 1.00 & 1.00 \\
Employment) & & & \\
\hline
\end{tabular}

Source: Authors based on data from the US Census and County Business Patterns.

Note: Sensitivity and recovery indices are calculated by adapting the methodology of Martin (2012) from regional resilience to sectoral resilience. Employment sensitivity is calculated as the ratio of change in employment in the securities industry sector in a particular state between Q4 2008 and Q2 2010 relative to the change in employment in all industries at the US level. Recovery is defined in a similar way, however this is over the period Q2 2010-Q1 2016. $\Delta \mathrm{Es} / \mathrm{Es}=\beta^{*}(\Delta \mathrm{Ec} / \mathrm{Ec})$ - where $\Delta \mathrm{E} / \mathrm{E}$ is the percentage change in employment for the securities industry at the state level (Es) or for all industries at the country level (Ec) and $\beta$ is the sensitivity or recovery index depending on the timeframe chosen. 